\title{
Geographic Patterns and Socio-Economic Influences on Mobile Internet Access and Use in United States Counties
}

\author{
Avijit Sarkar \\ University of Redlands \\ avijit_sarkar@redlands.edu
}

\author{
James Pick \\ University of Redlands \\ james_pick@redlands.edu
}

\author{
Greg Moss \\ University of Redlands \\ greg_moss@redlands.edu
}

\begin{abstract}
As mobile devices rapidly proliferate and internet services expand concomitantly, a confluence of the two enables users to access the internet on their mobile-cellular devices for a variety of purposes. In this paper, we examine mobile adoption and mobile internet usage in 3,108 counties of the United States for e-entertainment and e-commerce purposes. Spatial patterns of mobile internet adoption and usage are explored to understand the extent of the mobile internet digital divide in the US. Using the Spatially Aware Technology Utilization Model, socio-economic, innovation, affordability, and social capital influences on mobile adoption and mobile internet use are examined. Spatial dimensions of county-level mobile internet activity and evidence of strong association of geodemographic and tariff variables emphasize the importance of market forces on mobile internet usage. Policies to bridge the mobile internet digital divide are recommended based upon the significant influence of market factors, innovation, and affordability.
\end{abstract}

\section{Introduction}

Recent data and reports of the National Telecommunications and Information Administration [1,2] of the United States (US from this point forward) Department of Commerce provide evidence of the increasing access and use of information and communications technologies (ICTs) by US consumers. Such expanding access and use have spanned computer adoption in the household, use of internet, broadband, and mobile internet services. Between 2000 2014, the expansion in per capita mobile-cellular subscriptions has outpaced both fixed-broadband subscriptions and internet usage [3]. This is consistent with larger global trends which show that the rate of mobile cellular proliferation (mobile cellular subscriptions per 100 population) has been more than twice that of computer adoption and internet adoption in the household, and percent of individuals using the internet [3].

Between 2000 and 2014, the overall base of mobilecellular subscriptions expanded from approximately 109 million to 355 million, while subscriptions per 100 population grew from 38 to 110 , an increase of $225 \%$ and $186 \%$ respectively. Perhaps more impressive is the growth in US households with mobile internet service at home, which increased from 25\% (22.8 million in July 2013) to almost $61 \%$ (56 million in July 2015) of all households with home internet use [1]. As mobile phone communication approaches near ubiquity, it is essential to understand broad geographic patterns of mobile usage in the US as well as factors that influence such usage. Such investigation is important in light of growing employment potential of the mobile applications industry given the rapid deployment of smartphones [4], increasing usage of smartphones across the age spectrum for economic transactions stemming from shopping online or instore, and the exceedingly important role of mobile usage in the growth of e-commerce in the US [5].

In this paper, we examine the spatial distribution of mobile internet access and usage in 3,108 counties in the lower 48 states of the US. We further analyze the influence of demographic, socio-economic, affordability, innovation, and social capital factors on various forms of mobile internet use - for example for financial and personal entertainment activities. Overall our work is motivated by a well-accepted concept of the digital divide, which calls for examining geographical dimensions of the access to ICTs especially the internet, as well as "the use of the internet for a wide variety of activities [6, pp. 5]." This study is unique since such a large-scale analysis of mobile internet activity in the US has not been attempted in the digital divide literature. Another novel purpose of this work is to focus on the use of mobile internet, rather than on access to the mobile internet. Specifically, we focus on two categories of mobile internet use - financial activities, such as online banking, and bill payment; and personal entertainment activities such as listening to music and watching live television. Our research questions are:

RQ1. Are geographic agglomerations of mobile internet usage for financial and personal entertainment activities present in US counties as estimated by cluster analysis?

RQ2. What are the associations of demographic, socioeconomic, educational, affordability, innovation, and social capital indicators with indicators of mobile internet use for financial and entertainment purposes, based on the sample of mobile internet usage in US counties?

RQ3. How do such associations vary among the categories of metropolitan, micropolitan, and rural US counties?

In the context of this research, mobile internet (MI from this point forward) is defined as Internet access through the cellular phone infrastructure [7].

The remainder of this paper is organized into sections on literature review, conceptual model of MI usage in US counties, description of methodology, spatial dimensions of 
MI activity, regression results, policy implications, limitations and conclusions.

\section{Literature Review}

Tracking internet access and use in relation to the US household characteristics such as income, education, race and ethnicity, gender, and employment and geographic factors such as population density and place of internet access has been at the forefront of initiatives of the National Telecommunications and Information Administration (NTIA) over the past decade. In recent years, the NTIA has prominently focused on tracking and promoting broadband adoption through initiatives such as BroadbandUSA and the National Broadband Map. This focus has largely sidestepped the issue of use. In fact, we argue that having access to the internet or broadband has often been conflated with purposeful use of the technology. It is therefore not surprising that studies of the digital divide in the US have largely focused on internet and broadband access in recent years $[8,9,10,11]$. In such studies, the influences of demographic factors, economic factors, geographic factors $[8,9,10,11,12]$ as well as the roles of social interactions and social capital [8,9] and computer ownership [13] have been examined using various theories and empirical approaches. Prior studies of the US digital divide [14] have also examined geodemographic and social capital relationships with one of multiple ICT access dependent variables. Examining the purpose of mobile-driven internet use and the geodemographic influences on such usage has so far been largely neglected.

However, attention has shifted towards examining patterns of online usage of the US internet users. The US Census Bureau's July 2011 Current Population Survey (CPS) Computer and Internet Use Supplement included a significant new series of questions regarding online activities of the US internet user. This included online activities such as shopping and making travel reservations, obtaining financial, health, insurance information, searching for jobs, and sending emails and text messages. A recent NTIA report on US users embracing MI [2] not only details the role of income, race and ethnicity, employment status, and location on MI access, but it also examines the purpose of MI use for personal activities such as web browsing, texting, downloading apps, social networking, and entertainment activities of listening to music and playing games, with crossclassification by age, race, income, employment status, and urban versus rural location. From a global perspective, an early study examined the influence of cultural factors on MI usage among Korean and Japanese users for frequently used online activities such as emailing, texting, obtaining news, weather, sports information, accessing financial, ecommerce, and e-entertainment services [15]. However systematic examination of MI usage by US internet users and analysis of geographic patterns and socio-economic correlates of such usage has not been attempted in prior US digital divide literature. Our work attempts to fill this void.

It is essential to note that our investigation focuses on geographic patterns of MI usage in the US at the county level. We categorize counties as metropolitan, micropolitan, and rural in recognition of the geographic dimension of the digital divide. According to the US Census Bureau, metropolitan and micropolitan counties both contain core urban areas, with a population of at least 50,000 for metropolitan counties and between 10,000 and 50,000 for micropolitan counties. Each metropolitan or micropolitan area consists of one or more counties containing the core urban area, as well as any adjacent counties that have a high degree of social and economic integration with the urban core. Rural counties comprise all population, housing, and territory not included within metropolitan or micropolitan counties, together referred to as urban counties.

\section{Conceptual Model}

Theoretical models of technology adoption and usage such as Adoption-Diffusion Theory (ADT) [16], Unified Theory of Acceptance and Use of Technology (UTAUT) [17], and more specific models of technology access and adoption such as Van Dijk's Theory of Digital Technology Access and Societal Impacts [18] have been used in several prior digital divide studies. In this section, we outline and describe the Spatially Aware Technology Utilization Model (SATUM), used to examine spatial patterns of MI adoption and use and analyze socio-economic associations of such usage [14]. SATUM's features have been compared and contrasted with ADT, UTAUT, and Van Dijk's model in prior work [14].

Using SATUM, associations of the 17 independent demographic, socio-economic, locational, affordability, innovation, and social capital variables with 18 variables of MI access and usage are posited, based upon prior literature. A distinguishing feature of SATUM is its explicit consideration of geographic variation of technology adoption, in this case, spatial patterns and possible agglomeration of MI activity in US counties. While county is the geographic unit of analysis in the present study, SATUM works well for other units of geography, such as zip codes, census tracts, provinces, cities, states, and nations.

For dependent variables, we use 3 indicators of MI access, 9 indicators of MI usage for personal and entertainment purposes, and 6 indicators of MI use for financial activities. Examples of access indicators are households with at least one mobile cellular telephone and household expenditures for cellphone service. For entertainment use of MI, we incorporate dependent variables such as using cellphone to access news information and to watch a video clip [19]. For financial activities, we employ dependent variables such as using cellphone to perform online banking transactions and pay bills online [1]. All dependent variables used in the three previously mentioned categories along with their independent correlates are shown in our depiction of SATUM in Figure 1.

Next we discuss independent variables included in SATUM that are posited to be associated with 18 dependent indicators of MI access and usage. Inclusion of independent variables is mostly based upon prior literature and conceptual reasoning and is justified by categories as follows. 
Demographic influences: The significant influence of age, race and ethnicity, and place of domicile on the adoption, access, and use of ICTs such as the internet and broadband has been consistently documented in reports of the NTIA $[1,2,20]$. A recent report [2] indicates that racial disparities in mobile phone adoption nearly vanished by 2012 with close to 90 percent of Whites, African-Americans, Hispanic, and Asians aged 2 years and older using mobile phones. Similar to mobile phone adoption, use of MI does not vary dramatically by race [2].

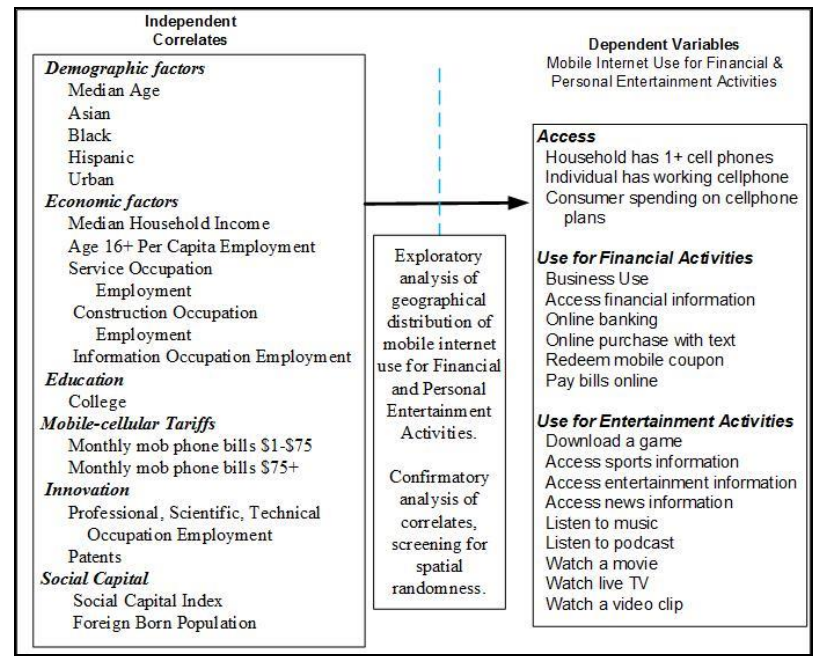

Figure 1: Conceptual Model of MI Utilization, US Counties

Interestingly however, while the mobile phone adoption gap between urban and rural Americans is modest and shrinking, in stark contrast, use of internet-based mobile applications varied dramatically by urban/rural category [2]. Rural users were consistently found to lag their urban counterparts by 8 to 15 percent in terms of using MI for checking and sending email, browsing the web, downloading apps, and utilizing social networks. The disparity in internet access and in overall ICT usage has been documented extensively in the digital divide literature $[8,9,21,22,23]$. We therefore include per capita urban population and three race and ethnic indicators as independent correlates.

Recent evidence from the digital divide literature suggests that older adults who tend to be economically, socioculturally, or physically disadvantaged are less likely to have reliable Internet access [24]. NTIA's Digital Nation Data Explorer [1] shows that there is almost a 40 percent gap in per capita mobile phone usage between users aged $65+$ compared to those aged $25-44$ in 2015. While that gap continues to be significant for internet use in entertainment activities such as watching videos, the disparity shrinks somewhat for financial activities such as online banking, bill payment, and online investing. The inverse association of age with the adoption and use of ICTs has been repeatedly documented in the digital divide literature [9]. Median age is therefore included as an independent variable in our model.

Education influences: From the perspective of educational attainment, mobile phone users aged $25+$ with a college degree were found to be more likely to check and send email using their mobile devices compared to those without a college degree $(57 \%$ of all college graduates versus $45 \%$ of those with some college credit). The discrepancy in browsing the web using MI was considerably higher between college graduates and those without a high school diploma [1]. The influence of education on the digital divide especially in the USA, is well-known $[8,9,11,23]$. NTIA's report [2] further documents that while individuals with lower levels of educational attainment narrowed the adoption gap in mobile phone use with their highly-educated counterparts between 2011 and 2012, the discrepancy in mobile phone usage between those with or without a highschool diploma and college graduates is significant. We therefore posit college education to be positively associated with the access of mobile-cellular phones and MI usage.

Economic Influences: NTIA's recent report [2] has provided evidence of acceleration in mobile phone use among historically lagging groups such as the less wealthy and less educated. The same report however cautions that use of MI differs greatly based upon income. We therefore introduce median household income as an independent variable and posit income to be positively associated with MI use. The same report provides evidence that being employed is associated with higher rate of internet-based activities on mobile devices. This is intuitive since being employed may induce spillover effects on mobile usage for personal purposes. This justifies inclusion of per capita employment age $16+$ as an independent variable. Employment in the services sector and information sector are also introduced as independent variables. Other services workforce may provide lower-level, non-technology and non-professional services to the technology enterprise and was found to be positively associated with technology receipts and payroll [25]. We posit that the information sector - comprised of software publishing, traditional and online publishing, motion picture, sound-recording, and broadcasting industries, telecommunications industry, web search portals, and data processing enterprises [26] in the "big data" age is likely to positively influence ICT adoption and especially MI services. Lastly, construction costs, specifically installation and maintenance expenses, were found to be associated with the probability of cell tower location in a spatial econometric study of cell phone coverage [27]. We argue that per capita size of the construction sector will impact physical and infrastructural aspects of ICT development and hence we introduce construction employment as an independent factor in our model.

Innovation Influences: Innovation has manifested itself in different forms in the digital divide literature and has been found to positively influence technology adoption and usage $[25,28]$. The professional, scientific, and technical services (PST) sector - comprised of subsectors such as computer systems design, management, scientific and technical consulting services, scientific research and development, and advertising services was a dominant correlate of technology receipts and payroll dependent variables in a study limited to 164 US counties [25]. The diffusion of innovation research points to the role of patents in the expansion of technology adoption and usage. Consequently, we introduce professional, scientific, and technical services employment and registered patents per county as independent variables. 
Affordability Influences: In its latest Computer and Internet Use Supplement of the Current Population Survey (CPS) of the US Census Bureau [1], affordability and monthly data limits are two of the seven most important factors listed as influencing the consumers' decision to obtain internet service in the household. Additionally, survey data from 122 million households in the 2012 CPS indicate that the expense of using internet at home remained as the second most cited reason non-internet households did not use the internet at home.

Recent research [29] has indicated that MI tariff type has a considerable impact on MI usage levels. "Flat" MI rate plans, whose charge is independent of the amount of one's MI data volume, seems to positively impact an individual's MI use compared to usage dependent pricing schemes. This seems intuitive. Conducting financial or entertainment activities using MI often calls for the adoption of mobile data plans. Depending on the extent and sophistication of such usage, higher end data plans may be required. Reasoning that such plans are costlier, we include two monthly tariff variables as independent indicators of affordability.

Social Capital Influences: Cautioning that social capital by itself is not a panacea for bridging differences in internet adoption, a recent study [9] found that having bonds with people who possess resources, i.e. implying a rubbing-off of knowledge of the internet would positively influence the likelihood that a non-adopter adopts and uses the internet. The effect of internet use by peers on an individual's decision to go online was found to be stronger in communities with strong social interactions [8]. A prior state-level study by the authors [14] found social capital, measured by an index, to positively influence adoption and use of computers in the household and adoption of internet and broadband in the home. Given the likelihood that immigrant communities are tightknit and socially connected, we posit that social capital and immigrant populations are positively associated with mobile-cellular adoption and MI use. Accordingly, we include a county-level index of social capital [30] and foreign born population per capita as independent variables.

\section{Methodology}

\subsection{Data Analysis}

Our methodology combines geographical mapping of MI use dependent variables with traditional multivariate analysis to examine associations of independent variables with these dependent variables. The following steps comprise our methodology: (i) descriptive statistics of all dependent and independent variables are first computed and correlation analysis is employed to examine multicollinearity among independent variables; (ii) MI use dependent variables are mapped using a Geographic Information System (GIS). These dependent variable maps show spatial distribution of the use of MI in US counties, enable us to examine patterns of usage of MI for personal financial and entertainment usage, and provide important visual cues about agglomeration of usage of MI in US counties; (iii) K-means clustering analysis is employed using a statistical software package (SPSS) to determine clusters of counties that are most similar in their usage of MI for financial and entertainment activities. In this study, K-means analysis with $\mathrm{K}=5$ clusters yields meaningful agglomerations of counties that are subsequently mapped using a GIS and characterized in terms of their usage of MI as well as their demographic, social and economic characteristics, and extent of innovation and social connectedness of the counties in the clusters; (iv) finally OLS regression analysis is employed to examine associations of demographic, socio-economic, social capital, and innovation independent variables on the MI usage dependent variables. OLS regressions are conducted for a total of 18 dependent variables, namely 3 MI access variables, 6 variables of MI use for economic activities, and 9 variables of MI usage for personal entertainment. The regression contains a pool of 17 socioeconomic and demographic independent variables. Stepwise entry of independent variables is employed with significance levels equal or less than 0.05 . As an additional test of multicollinearity, the variance inflation factor (VIF) is computed, and a cutoff value of 5.0 is used to screen for independent variables that might cause multicollinearity. All independent variables in the regressions, which are discussed later in Section 6, meet the VIF threshold.

\subsection{Data Collection}

Data on all 18 dependent variables of MI access and use for financial and personal entertainment dependent variables were obtained from Esri/GfK MRI DoubleBase Survey $[31,32]$. Estimates of demand in the form of an index for each of these dependent variables were used for the study; relevant methodology statements [31,32] document how such indices are computed. Data for a majority of the independent variables such as population, income, education, age, ethnicity, and employment are procured from US Census sources including the American Community Survey (ACS). Data on monthly mobile phone tariffs are obtained from Esri's Business Analyst [31]. For the social capital independent variable, we used an index for county-level social capital from the Pennsylvania State University's Northeast Regional Center for Rural Development [30]. Data for a number of independent variables are from the period 2008-2012 ensuring time simultaneity. Our county sample includes all 3,108 counties or county equivalents in the lower 48 states of the US as defined by the US Census Bureau in July 2009. Definitions, sources, and descriptive statistics of few dependent and independent variables appear in Table 1.

\section{Geographical Patterns of MI Use}

$\mathrm{K}$-means cluster analysis is conducted with $\mathrm{K}=5$ for the three categories of dependent variables - mobile cellular access, MI use for financial activities, and MI use for personal entertainment activities (Figure 2). Due to space constraints, in this section we characterize clusters of MI use for entertainment and compare and contrast characteristics with those of clusters resulting from MI use for financial activities.

Highest use of MI for entertainment (Cluster 1 counties depicted in red in Figure 2, 75 out of 3,108 counties, 2.41\% 
of total) are scattered across the US. Such counties either include major cities in well-known metropolitan areas (for example, San Francisco County CA, Boulder and Denver counties CO, Suffolk County MA which includes the city of Boston, Bronx and New York Counties NY which include Bronx and Manhattan boroughs of New York city, Philadelphia County PA, Arlington County VA, as well as the District of Columbia) or are counties that are home to large public research universities. Examples of the latter are Brazos County TX, Dekalb County IL, Alachua County FL, Clarke County GA, Champaign County IL, and Douglas County KS that include public research universities such as Texas Agricultural and Mechanical University (TAMU), Northern Illinois University, University of Florida at Gainesville, University of Georgia, University of Illinois at Urbana-Champaign, and University of Kansas respectively. This is an interesting, yet intuitive finding.

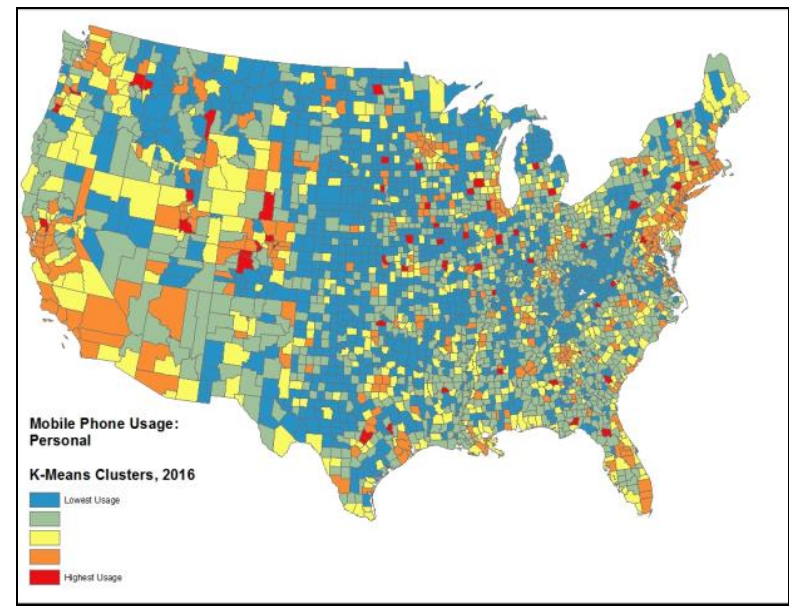

Figure 2: K-means Clusters of MI Use for Entertainment Activities, US Counties, 2015

Cluster 1 counties are young (average median age 31 years), well-educated (almost $40 \%$ of the county population have a Bachelors degree), relatively affluent (second highest median income cluster among 5 clusters), and have the highest average Asian population and professional, scientific, and technical services workforce per capita. Cluster 2 (second highest on MI use for entertainment) is comprised of counties (349 out of $3,108,11.23 \%$ of total) that are somewhat older and slightly lower in educational attainment compared to cluster 1 counties. Cluster 2 counties like those in cluster 1 are diverse in race, ethnicity, and foreign born population per capita and also alike from a broad economic perspective. Almost $97 \%$ of all counties in clusters 1 and 2 are either metropolitan or micropolitan, indicating that use of MI for entertainment purposes is relatively high in regions with high population densities. In other words, the "creative class" [33] - young, educated, affluent, technologically proficient, employed residents of clusters 1 and 2 provide a critical mass of demand for internet services to access music, movies, streaming videos, podcasts, news, and other entertainment on their mobile devices.

Clusters 4 and 5 are at the low end of the spectrum (blue and green counties in Figure 2) for MI use for entertainment.
Such counties comprise over two-thirds of all counties in our sample $(32.75 \%$ and $37.03 \%$ respectively). In contrast to counties in clusters 1 and 2, counties in clusters 4 and 5 are older (average median age over 40 years), lower in educational attainment (no more than 17 percent Bachelors on the average), less diverse, and less wealthy. From an economic perspective, cluster 4 and 5 counties lag their counterparts in clusters 1 and 2 in terms of per capita employment in professional, scientific, and technical services, slightly exceed in per capita employment in construction, and compare favorably in per capita employment in the services sector. $44.30 \%$ of all cluster 5 counties are rural while another $51 \%$ are micropolitan indicating that demand for MI use for entertainment is lower due to lower population density. As evident from Figure 2, counties in clusters 4 and 5 span a vast north-south central band as well as large parts of the Rust Belt and south-eastern US - parts of the country that have traditionally been acknowledged as laggards in the adoption of diffusion of ICTs. The digital divide between clusters 4 and 5 compared to clusters 1 and 2 is also evident from the highest-to-lowest use ratios which vary from 1.78 for using MI to listen to music to 7.86 for using MI to listen to a podcast. Overall, the ratio of highest to lowest MI use exceeds 2.0 for 7 out of the $9(78 \%)$ of the entertainment dependent variables.

K-means analysis of MI use for financial activities presents an interesting contrast compared to entertainment activities. High levels of MI usage for business use, online banking, online bill payment, accessing financial information, and redeeming coupons are found in populous, urban metros spanning the West Coast (San Francisco to San Diego CA), Pacific Northwest (Seattle), Chicago, Minneapolis-St. Paul metros in the Midwest, the telework corridor between Denver CO and Salt Lake City UT in the Rockies, Atlanta GA and Orlando, Miami FL in the south and south-east, and most importantly the North-East megalopolis spanning from Washington D.C. in the south up to Boston MA, New Hampshire and Vermont in the north.

This presents a notable contrast in comparison to the clusters of MI use for entertainment which are scattered across select metros but are more common in "university towns". While only $13.6 \%$ of all counties $(n=3,108)$ are in the high entertainment use clusters, almost half of all US counties $(48.7 \%)$ demonstrate high use of MI for business and financial activities. This points to a more mature, geographically diverse base of high MI users in the realm of business and financial use.

We conclude this section with an observation with empirical implications. Figure 2 indicates that the high use entertainment counties are almost always surrounded by vast areas of low-moderate use. In other words, such counties are likely to be high use "outliers"; the statistical significance of which may be tested by cluster and outlier analysis using measures such as Moran's I [21]. While K-means analysis is largely exploratory but provides interesting insights about the spatial distribution of MI usage among US counties, Moran's I analysis is confirmatory; it yields statistically significant "hotspots" or "coldspots" - areas of high/low use surrounded by similar areas of high/low use, as well as statistically significant outliers (such as high MI use university towns in largely rural communities, for example Latah County ID and 
Whitman County WA, home to University of Idaho and Washington State University respectively). Such statistically significant agglomerations often point to spatial autocorrelation - a common issue that plagues problems in economic geography as well as adoption and use of technologies, and underlines the importance of geography in examining digital divides. We outline spatial autocorrelation modeling of the dependent variables and accounting for spatial bias in OLS regression models as ongoing work and present this as a future research direction for our work.

\section{Regression Findings}

\section{Mobile Phone Access Results}

The findings for mobile phone access reveal some expected results on education, income, and employment, along with new findings on ethnicities, while other previously important factors are unimportant. Findings for correlates of mobile phone access across the metropolitan/micropolitan/urban subsamples conforms fairly closely to the overall country sample.

The regression findings for mobile phone access at the county level, including metropolitan, micropolitan, and rural samples have highly significant adjusted $\mathrm{R}^{2}$ values that represent large effect size, since the variance explained is between 26.7 percent and 85.2 percent. Since the samples are large, ranging from 671 for the rural counties to 3,108 for the nation, $p$-values alone are not a sufficient indicator of importance but need to be combined with effect size [34,35]. For the nation and metro/micro/rural subsamples, the most important correlates are college education and income. College education is well-known as a technology determinant for the U.S. [8,9,11], for small economic units in the European Union [36], and for national samples [14].

Household income is strongly related to household consumer spending on cell phone service for the nation ( $<<.001)$ and subsamples, a plausible finding since higher income connotes improved ability to pay for cell service, and also consistent with the literature $[37,38,39]$. A study of the relationship of internet use with income for 2000-2015 indicated a positive correlation, although a gradual lessening of strength over time [40], while another study of individuals indicated only a small difference in college education between mobile phone users and non-users of internet/cellphones, while combined internet/cellphone users were much more likely to be college educated [39]. Percent urban is an important correlate of two access variables, households with $1+$ cell phones and an individual with a working cell phone $(\mathrm{p}<.001)$. This is consistent with findings of random samples of individuals in the U.S. for the period 2000-2015, which revealed a 7 percent gap between access of urban/suburban Internet users compared to rural counterparts [40]. This was ascribed to rural respondents tending to have lower education, lower income, and older age. The same explanation can be applied to U.S. counties.

Employment in Professional, Scientific, and Technical (PST) occupations, although important in a prior U.S. county study [25], is related only to household spending on phone service for the nation, and slightly for rural counties, while inversely related for households with $1+$ cell phone in metropolitan counties. Its general lack of importance and inconsistent directionality is unexplained. By contrast, service occupation is consistently related across samples to household with $1+$ cell phone, a finding supported by a prior county study [25]. We reason that service workers have more need for mobile phones occupationally, due to need to communicate on many levels with customers, suppliers, and co-workers.

The findings on ethnicities indicate that, for counties, mobile phone access is strongly and almost without exception correlated with African-American ethnicity, a novel result that differs from studies in which Black ethnicity is associated with reduced technology use $[20,23,40]$. This finding points to a positive trend in cell phone access for counties with higher ratios of Blacks, which implies a greater strength and perhaps catch-up taking place for Blacks in county-wide cell phone access. This is reflected in their having the highest rate of increase in internet access increase among ethnic groups from 2005 to 2012 [40]. By contrast, there are no significant findings for Asian ethnicity and cell phone access. This finding likely relates to a level of individual Asian access to the Internet in 2015 that averaged 97 percent [40]. If Asian population is nearing saturation on cell phones, then percent Asian should strongly impact county cell phone access. However, it may also be that Asians are moving somewhat away from cell phones and diversifying their technology use with tablets, wearables, and other advanced wireless devices.

There are fairly strong results that cell phone access is reduced by low mobile phone bills and increased by high mobile phone bills. These effects are present for about half of the cell phone access variables and consistent across the samples. Since there is relatively little literature on impacts of cell phone tariffs, we reason that with higher-level cellular subscriptions, there is more motivation for households to utilize more expensive cell phone services, as well as spread usage to others to a greater extent. Social capital reveals almost no relationship to dependent variables (only weakly to computer spending on cell phone service in rural areas), while foreign-born population, a proxy for social capital, is related to households with one or more cell phones. The latter finding is explained by the youth of immigrant groups, as well as their need to have cell phones to communicate with the immigrant as well as non-immigrant communities. The lack of findings for social capital correspond to lack of relationship of Putnam's social capital index with two mobile access variables, mobile wireless high-speed devices and with persons in cell-phone only household, in a study of technology access in U.S. states [14]. The latter study and other studies have shown a positive relationship between social capital and access to personal computers, internet, broadband and social media at the state level $[14,31,41]$.

\section{Mobile E-Commerce Usage Results}

The regression findings for mobile phone usage in ecommerce are highly significant as measured by $\mathrm{R}^{2}$, along with strong effect size shown with percent of variance explained in the four samples ranging from $21 \%$ to $72 \%$. For the nation as a whole, the most important correlates are median age, percent urban, education, income, professional, scientific, technical services occupation, and African American ethnicity. These findings are largely echoed in the 
metropolitan subsample, but weaken progressively in the micropolitan and rural subsamples.

For the nation, counties with higher percent urban, college graduation, and household income have elevated mobile e-commerce uses, findings which are reflected in metropolitan and micropolitan subsamples, and are consistent with extensive digital divide literature. However, the effects of college education and income weaken to only two strong effects for rural counties; in particular, college education is associated with cell phone use for business $(p<.001)$ and income is inversely related to using a cell phone to pay bills in the last 12 months $(\mathrm{p}<.001)$. It speculate that high-income rural counties have easier means to pay bills than using cell phones, such as presence of more bank branches, ATMs, and greater access to tablets and laptops.

PST occupations are strongly associated with ecommerce usage, a pattern also reflected in rural counties, and somewhat in metropolitan ones. This finding corresponds to a prior study of a 5 percent sample of U.S. counties, in which PST workforce was the strongest independent factor associated with receipts and payrolls in the IS-data processing sector and with broadcasting-telecommunication sector receipts and payrolls [25]. PST workers tend to have high technology skills, which would enable them to overcome some of the isolation of rural areas in their work through increased usage of e-commerce. Although information occupation had almost no associations (two weak ones in rural counties), service occupations are strong for half the variables for the national, micropolitan, and rural samples, and for five variables for the metropolitan sample. This corresponds to widespread significance of service occupations in the study just cited [25]. Our explanation is that service workforce increasingly makes purchases with cell phones and encourages customers to use cell phones to make purchases, do banking online, and redeem coupons.

By ethnicities, counties with high proportion of African Americans have strong associations with using cell phones for business use, obtaining financial information, making a purchase and redeeming a coupon, but an inverse association for bill payment with a cell phone. Similar strong findings are present for micropolitan and rural counties, although less prevalent for metropolitan counties. This novel result echoes the positive associations of Blacks with access to cell phones. It corresponds also, in a prior county investigation, to positive effects on receipts and payrolls in the broadcasting/telecommunications sector, but is opposite in effects for the IS-data processing and motion picture-sound sectors [25].

Findings for counties with higher Hispanic proportion reveal scattered inverse effects, with the exception of two positive correlates (using a cell phone to redeem a coupon and to pay bills) in metropolitan counties. The inverse effects are consistent with other studies indicating Hispanic population has lower technology usage $[20,23,40]$, while the positive effects were only seen for receipts and payrolls in the motion picture-sound sector [25] although convergence of Hispanic results with the national average has been confirmed for individual use of the MI in a recent NTIA study [2]. The associations of Asian population are seen only in the micropolitan subsample for use of the cell phone to access financial information, make a purchase, and redeem a coupon, findings consistent with higher technology use by Asians [40] but unexplained for presence in the micropolitan sample only.

There are strong effects of monthly bills (inverse for low bills and positive for high bills) on for the national and metropolitan samples, but not the others. The explanation in this case is somewhat similar to access, in particular that people in counties with higher mobile bills tend to be more intensive and broader users of mobile e-commerce applications. Nationwide, social capital is inverse in association for cell phones for business use, redeem a coupon, and pay bills, a finding that differs from lack of association of the Putnam social capital index with proportions of cell-phone-only households and users of mobile wireless high-speed devices [14]. There are scattered results for foreign born population, as a proxy for social capital. The overall paucity of social capital associations may be explained by increasing displacement of traditional physical social capital by diverse forms of virtual social networking, e.g. that the bowling club is being replaced by a virtual social group on bowling.

Patents, a proxy for innovation, appears as a strong correlate of mobile e-commerce usage only in the rural sample. Our arguments here are similar to those for rural PST employees, i.e. that R\&D innovators in rural settings would have likely migrated from metropolitan settings and find mobile e-commerce to be familiar and very useful, in lieu of having concentrations of brick-and-mortar retail and wholesale businesses.

\section{Mobile E-Entertainment Usage Results}

The regression findings (Table 2 ) for mobile phone usage in e-entertainment are highly significant for all four samples as measured by $\mathrm{R}^{2}$, along with strong effect size shown with percent of variance explained in the national, metropolitan, and micropolitan samples ranging from 45 to $72 \%$. However, the effect size for the rural sample has somewhat lower percent of variance explained that ranges from 19 to $39 \%$, so its practical importance must be viewed more cautiously $[34,35]$.

For the nation, there are strong effects of urban location, college graduation, and strong inverse effect of median age (all $\mathrm{p}<.001$ ), results echoing those in the metropolitan and micropolitan samples, with college graduation less prevalent in the rural sample. The explanations of these well-known effects are similar to those given for mobile e-commerce. Household income differs from the e-commerce findings. For the nation, it is mixed in direction for four e-entertainment uses, while for metropolitan and micropolitan counties it is more heavily positive in effects. However, in rural counties, higher income relates to reduced mobile e-entertainment for two thirds of the e-entertainment variables. The turn-around for rural counties may be explained by low income households finding mobile e-entertainment to be the cheapest usage. In a rural setting, live sources of entertainment would be more distant and expensive, and cell phones less expensive than usage through desktops, laptops, or tablets, which would be more expensive to assemble and maintain than in urban settings.

Nationwide for counties, PST employment is positive for most mobile-entertainment variables, moderately prevalent 
for the metropolitan sample, and without effect for the micropolitan sample, and positive for mobile-entertainment variables for the rural sample. These findings point to the rural counties as the locations where PST employment impacts mobile e-entertainment. This finding may reflect the high technology skills of PST employees, which enable them to be skilled at finding e-entertainment apps and also have greater interest in exploring the range of possibilities in games, sports, entertainment information, news, music, etc.

Service occupations show strong connection with nearly all the e-entertainment variables across all four samples. This finding corroborates a literature finding for a sample of U.S. counties for which service employment was significantly correlated with receipts/payroll for the broadcasting/telecommunications and motion picture/sound sectors [25].

By ethnicities, African American population again reveals positive results across the four samples, with explanation similar to that for e-commerce. Effects of Hispanic ethnicity tend to be inverse for some eentertainment variables in the nation and micropolitan samples, but have no effect in the metropolitan sample and are mixed in directionality for the rural sample; these differences are unexplained and point to future research. Asian effects are positive for the national and rural samples; not present of the metropolitan sample; but especially strong and widespread for micropolitan counties. For the latter, we argue that Asian population is spreading from gateway counties to smaller urban settings, in which Asians as newcomers and generally intensive technology users, find eentertainment as a way to connect with broader Asian world that tends to be metropolitan-based.

Social capital for the nation is inverse for cell phone downloading games, accessing sports, and watching movies and live TV. We reason that counties having residents with high social capital, i.e. with high physical networking with other people, have less time and need to use cell phones for entertainment. The three subsamples have no social capital effects. Foreign born population effects are present sporadically, except not present for the rural sample, and its particular effects unexplained. There is almost no relationship of patents with e-entertainment factors, which is unsurprising given that the $R \& D$ represented by patents applies less to the consumer-oriented e-entertainment sector.

\section{Policy Implications}

Study findings can inform county, state, and federal policymakers about improving MI access and use in order to provide pertinent information and knowledge, and improve the productivity of people in their roles as citizens, consumers, government workers, and business decisionmakers. County government can better accomplish its many responsibilities by better informing the public, communicating interactively, exchanging goods and services, and improving efficiency. Based on study findings, the following are policy recommendations for counties.

1. Emphasize support for education at all levels through assistance and funding to K-12 and community colleges, as well as county training programs. This is because educational attainment is consistently positively associated with MI access as well as usage - both for commercial and entertainment purposes. The goal would be to improve educational levels for county citizens across age groups and at varied educational levels. States are encouraged to focus on support in public higher education for education and training in mobile e-commerce and e-entertainment. This might be achieved by providing special funding to motivate universities to establish requirements for students to learn about these rapidly advancing mobile technologies.

2. Develop policies to assist and train older citizens to make broader and deeper use of mobile phones. Although older people have increasing access to mobile phones, they are trailing on nearly every type of usage in the e-commerce and e-entertainment realms. The policies would aspire to narrow the age divide by building the technology confidence of older people, motiving them through identifying e-commerce and eentertainment applications of high relevancy, and following through with post-training over time so the door on these new opportunities does not close again.

3. For micropolitan or rural counties, customize policies that will be particularly effective in currently less favorable environments for mobile e-commerce and eentertainment usage. For instance, since our study identified PST workforce as particularly associated with growth of this usage, county policymakers could seek to fund and set up rural technology hubs where PST employees could voluntarily share some of the means to enhance range and depth of mobile phone uses. County policymakers could also establish programs to involve PST employees in rural areas in sharing knowledge of these uses in K-12 settings.

4. Encourage technology usage among deprived ethnic groups to expand mobile phone e-commerce and eentertainment uses. Since the study found the association of Hispanic ethnicity with such usage to be the lowest among the triad - Asian, Black, and Hispanic, county policies could include targeted funding for training/education in mobile applications in schools/community colleges with high Hispanic enrollments, as well as support, assistance, or funding development of some Spanish-language training materials. Even though this study indicated that Black population is associated with increased uses of these technologies, other studies have indicated Black's general usage is low, so special programs might also be developed/supported for these citizens.

At the state and federal levels, a somewhat different set of policies are recommended including the following.

1. For the federal government, set policies to establish regular data collection on mobile technologies at the county or sub-county levels. Presently, such data does not exist on a regular collection basis even for states, which is in contrast to many other nations that regularly collect it down to the county or district level, e.g. China. With much greater nationwide data on small area mobile phone and other technologies, county governments, economic 
planning units, businesses and consumers would be better informed about deficits that could be identified and realistic milestones set to overcome the deficits.

2. States and the federal government could set policies to encourage small businesses and non-profit organizations to engage in substantive learning about the benefits of mobile technology structures and applications and make greater use of them with goals of reducing divides and disparities in usage among different socio-economic and demographic segments of counties.

\section{Limitations and Conclusions}

Communications industry professionals contend that compared to mobile voice communications which have matured, MI is still at an early stage of evolution. Already MI has become a platform for popular applications such as instant messaging, online gaming, multimedia (e.g., video and audio streaming), financial services (e.g., banking), search, and mapping and location-based services [7]. This paper is the first systematic attempt to examine patterns of mobile cellular adoption and MI use in US counties. Spatial distributions of MI use for entertainment and financial activities yield interesting insights about the MI digital divide in the US. Age, urban location, education, participation in the services - more specifically professional, scientific, and technical services workforce are dominant correlates of MI use while tariffs and race and ethnicities (Hispanic and African American) are associated with varying degrees. These broadly point to the influence of key demographics, location, innovation, and affordability on MI use.

In this work, MI use for social networking purposes identified as a popular use of MI by the NTIA has not been included, primarily due to the lack of reliable county-level data. However this may soon be possible using reliable MI use data from Census surveys, particularly the US Census Bureau's recent Current Population Survey. As acknowledged earlier, agglomeration of mobile access and MI use indicates possible presence of spatial autocorrelation. Accounting for spatial bias can be accomplished by computing spatial autocorrelation of dependent variables as well as regression residuals and is outlined as a future research direction.

\section{References}

[1] NTIA, Digital Nation Data Explorer, Retrieved from https://www.ntia.doc.gov/other-publication/2016/digitalnation-data-explorer on June 1, 2016.

[2] NTIA, "Exploring the Digital nation: Embracing the Mobile Internet," National telecommunications and Information Admin., U.S. Dept. of Commerce, Washington, DC, 2014.

[3] ITU, International Telecommunications Union Statistics, Retrieved from http://www.itu.int/en/ITUD/Statistics/Pages/stat/default.aspx on June 1, 2016.

[4] Mandel, M. (2013, Jul. 8). 752,000 app economy jobs on the 5th anniversary of the app store. Progressive Policy Institute.

Retrieved http://www.progressivepolicy.org/2013/07/752000-appeconomy-jobs-on-the-5th-anniversary-of-the-app-store/. [5] Mulpuru, S. (2014, May 12). US mobile phone and tablet commerce forecast, 2013 to 2018. Forrester Research. Retrieved from

http://www.forrester.com/US+Mobile+Phone+And+Tablet+ Commerce+Forecast+2013+To+2018/fulltext//ERES115514 ?intcmp=blog:forrlink.

[6] OECD, "Understanding the digital divide," OECD Digital Economy Papers, No. 49, OECD Publishing, Paris, 2011.

[7] Y.M. Shin, S.C. Lee, B. Shin, and H.G. Lee, "Examining influencing factors of post-adoption usage of mobile internet: Focus on the user perception of supplier-side attributes", Information Systems Frontiers, 12, 2010, pp. 595-606.

[8] R. Agarwal, A. Animesh, and K. Prasad, "Social interactions and the 'digital divide': Explaining variations in internet use”, Information Systems Research, 20(2), 2009, 277-294.

[9] W. Chen, "The implications of social capital for the digital divides in America," The Information Society, 29, 2013, pp. 13-25.

[10] J.E. Prieger, "The broadband digital divide and the economic benefits of mobile broadband for rural areas", Telecommunications Policy, 37, 2013, 483-502.

[11] M.D. Weiner, O.T. Puniello, R.B. Noland, C.D, Turakhai, "Consider the non-adopter: developing a prediction model for the adoption of household level broadband access", Socio-Economic Planning Sciences, 46, 2012, pp. 183-193.

[12] T.H. Grubesic, "Spatial dimensions of internet activity", Telecommunications Policy, 26, 2002, pp. 363-387.

[13] J. Chakraborty, and M.M. Bosman, "Measuring the Digital Divide in the United States: Race, Income, and Personal Computer Ownership", The Professional Geographer, 57(3), 2005, pp. 395-410.

[14] J. Pick, A. Sarkar and J. Johnson, "United States digital divide: State level analysis of spatial clustering and multivariate determinants of ICT utilization", SocioEconomic Planning Sciences, 49, 2015, 16-32.

[15] Y. Lee, J. Kim, I. Lee, and H. Kim, "A cross-cultural study on the value structure of mobile internet usage: Comparison between Korea and Japan", Journal of Electronic Commerce Research, 3, 2002, 227-239.

[16] E. Rogers, Diffusion of Innovations, $5^{\text {th }}$ edition, Free Press, New York, NY, 2003.

[17] V. Venkatesh, M. G. Morris, G. B. Davis, F. D. Davis, "User Acceptance of Information Technology: Toward a Unified View", MIS Quarterly, (27: 3), 2003, pp. 425-478.

[18] van Dijk, J.A.G.M., "The Network Society: Social Aspects of New Media", Sage, London, 1999.

[19] M. Warschauer, and T. Matuchniak, "New technology and digital worlds: Analyzing evidence of equity in access, use, and outcomes", Review of Research in Education, 34(1), 2010, pp. 179-225.

[20] NTIA. Exploring the Digital Nation: Computer and Internet Usage at Home. National Telecommunications and Information Administration, U.S. Department of Commerce, Washington, D.C.: 2011.

[21] L.K. Khatiwada, and K.E. Pigg, "Internet service provision in the U.S. counties: Is spatial pattern a function of 
demand", American Behavioral Scientist, 53(9), 2010, 13261343.

[22] The White House. 2015. Mapping the digital divide. Retrieved

from https://www.whitehouse.gov/sites/default/files/wh digital di vide_issue brief.pdf on November 1, 2015.

[23] C. Tolbert, K. Mossberger, B. King, and G. Miller, "Are all American Women Making Progress Online? AfricanAmericans and Latinas", Information Technologies and International Development, 4(2), 207, pp. 61-88.

[24] R.P. Yu, N.B. Ellison, R.J. McCammon, and K. M. Langa, "Mapping the two levels of digital divide: Internet access and social network site adoption among older adults in the USA", Information, Communication \& Society, 19(10), 2016, pp. 1445-1464.

[25] R. Azari, and J. Pick, "Technology and society: socioeconomic influences on technological sectors for United States counties", International Journal of Information Management, 25, 2005, pp. 21-37.

[26] Bureau of Labor Statistics, Information: NAICS 51, Retrieved from http://www.bls.gov/iag/tgs/iag51.htm on June 10, 2016.

[27] P. Buys, S. Dasgupta, T. Thomas, and D. Wheeler, "Determinants of a digital divide in sub-Saharan Africa: A spatial econometric analysis of cell phone coverage", World Development, 37(9), 2009, pp. 1494-1505.

[28] M.G. Quibria, S.N. Ahmed, T. Tschang, and M.-L. Reyes-Macasaquit," "Digital divide: determinants and policies with special reference to Asia", Journal of Asian Economics, 13, 2003, pp. 188-825.

[29] T.J. Gerpott, and S. Thomas, "Empirical research on mobile Internet usage: A meta-analysis of the literature", Telecommunications Policy, 38, 2014, pp. 291-310.

[30] A. Rupasingha, and S.J. Goetz, US County-Level Social Capital Data, 1990-2005. Penn State University, University Park, PA: The Northeast Regional Center for Rural Development, 2008.

[31] Esri. Business Analyst. Retrieved from http://www.esri.com/software/businessanalyst, May 1, 2014.

[32] Esri. 2013 US market potential data methodology statement. Retrieved from http://support.esri.com/en/knowledgebase/whitepapers/view/ productid/153/metaid/2037, 2015.

[33] Florida, R.L. "The rise of the creative class, revisited", Basic Books, New York, 2012.

[34] Nuzzo, R. "Scientific Method: Statistical Errors", Nature, 506, 2014, pp. 150-152.

[35] R.L. Wasserstein, and N.A. Lazar, "The ASA's Statement on P-Values: Context, Process, and Purpose", The American Statistician, 70(2), 2016, pp. 129-133.

[36] M.R.Vicente, and A.J. Lopez, "Assessing the regional divide across the European Union-27", Telecommunications Policy 13, 2011, pp. 220-237.

[37] M. Baliamoune-Lutz, "An Analysis of the Determinants and Effects of ICT Diffusion in Developing Countries",
Information Technology for Development 10(3), 2003, pp. 151-169.

[38] M.F. Guillén, and S.I. Suárez, "Explaining the Global Digital Divide: Economic, Political, and Sociological Drivers of Cross-national Internet Use", Social Force, 84(2), 2004, pp. 681-708.

[39] R.E. Rice, and J.E. Katz., "Comparing Internet and Mobile Phone Usage: Digital Divides of Usage, Adoption, and Dropouts", Telecommunications Policy, 27, 2003, pp. 597-623.

[40] A., Perrin, and M. Duggan. Americans' Internet Access: 2000-2015. Report. Washington, D.C.: Pew Research Center, 2015.

[41] S. Zhao, "Do Internet Users Have More Social Ties? A Call for Differentiated Analysis of Internet Use", Journal of Computer-Mediated Communication, 11, 2006, pp. 844-862.

\section{Table 1: Definitions and Descriptive Statistics of} Selected Dependent \& Independent Variables

\begin{tabular}{|c|c|c|c|c|c|}
\hline Definition & $\begin{array}{l}\text { Year of } \\
\text { Data }\end{array}$ & Min & Max & Mean & $S D$ \\
\hline $\begin{array}{l}\text { Mobile internet used to do } \\
\text { banking in the last } 12 \text { months } \\
\text { (index) }{ }^{1}\end{array}$ & 2015 & 30 & 154 & 73.58 & 24.47 \\
\hline $\begin{array}{l}\text { Mobile internet used to pay bill } \\
\text { in the last } 12 \text { months (index) }{ }^{1}\end{array}$ & 2015 & 30 & 168 & 87.77 & 16.87 \\
\hline $\begin{array}{l}\text { Mobile internet used to } \\
\text { download a game in the last } 30 \\
\text { days (index) }{ }^{1}\end{array}$ & 2015 & 38 & 124 & 82.32 & 16.91 \\
\hline $\begin{array}{l}\text { Mobile internet used to listen } \\
\text { to music in the last } 30 \text { days } \\
\text { (index) }{ }^{1}\end{array}$ & 2015 & 44 & 131 & 80.42 & 16.66 \\
\hline $\begin{array}{l}\text { Mobile internet used to watch a } \\
\text { movie in the last } 30 \text { days } \\
\text { (index) }{ }^{1}\end{array}$ & 2015 & 31 & 224 & 74.19 & 25.24 \\
\hline $\begin{array}{l}\text { Household has } 1 \text { or more Cell } \\
\text { phones (index) }{ }^{1}\end{array}$ & 2015 & 82 & 104 & 97.53 & 2.93 \\
\hline $\begin{array}{l}\text { Population with Bachelors } \\
\text { degree or higher }(\%)^{2}\end{array}$ & 2010-2014 & 2.60 & 75.10 & 20.07 & 8.92 \\
\hline Median Age of Population ${ }^{2}$ & 2010-2014 & 21.60 & 64.50 & 40.75 & 5.20 \\
\hline Median Household Income ${ }^{2}$ & 2010-2014 & 19146.00 & 123966.00 & 46357.94 & 11944.23 \\
\hline $\begin{array}{l}\text { Percent of employed Pop in } \\
\text { Professional, Scientific, and } \\
\text { Technology industries }{ }^{2}\end{array}$ & 2010-2014 & 0.00 & 53.16 & 3.52 & 2.47 \\
\hline $\begin{array}{l}\text { Average cell phone bill } \$ 75 \text { and } \\
\text { Up Indexed by County (index) }{ }^{1}\end{array}$ & 2015 & 68.00 & 120.00 & 92.83 & 8.80 \\
\hline $\begin{array}{l}\text { Tranformed Index of County } \\
\text { Social Capital }^{3}\end{array}$ & 2008 & 0.00 & 21.49 & 3.94 & 1.34 \\
\hline & & \multicolumn{4}{|c|}{$n=3,108$} \\
\hline SOURCES & \multicolumn{2}{|c|}{ Detailed Reference } & & & \\
\hline${ }^{1}$ Esri Business Analyst Data & \multicolumn{5}{|c|}{$\begin{array}{l}\text { Esri Business Analyst Data, GfK MRI DoubleBase Survey } \\
\qquad 2015\end{array}$} \\
\hline $\begin{array}{l}{ }^{2} \text { US Census Bureau, ACS 2014, } \\
\text { Table S0101 }\end{array}$ & \multicolumn{5}{|c|}{$\begin{array}{l}\text { US Census Bureau, American Community Survey 2014, 5- } \\
\text { year estimates, Table S0101 }\end{array}$} \\
\hline${ }^{3}$ Rupasingha and Goetz, 2008 & \multicolumn{5}{|c|}{$\begin{array}{l}\text { Pennsylvania State University's Northeast Regional } \\
\text { Center for Rural Development }\end{array}$} \\
\hline
\end{tabular}


Table 2: OLS Regressions Results, Mobile Internet Use for Entertainment, all US Counties $(n=3,108)$

\begin{tabular}{|c|c|c|c|c|c|c|c|c|c|}
\hline & CPDLGM30 & CPSPORT30 & CPENTER30 & CPNEW30 & CPLMUS30 & CPLPOD30 & CPMOV30 & CPLTV30 & CPVIDC30 \\
\hline $\begin{array}{l}\text { Independent Variable } \\
\text { Definition }\end{array}$ & $\begin{array}{l}\text { Used cell phone to } \\
\text { download a game in } \\
\text { past } 30 \text { days }\end{array}$ & $\begin{array}{l}\text { Used cell phone to } \\
\text { access sports info in } \\
\text { past } 30 \text { days }\end{array}$ & $\begin{array}{l}\text { Used cell phone to } \\
\text { access entertainment } \\
\text { info in past } 30 \text { days }\end{array}$ & $\begin{array}{l}\text { Used cell phone to } \\
\text { access news } \\
\text { information in past } 30 \\
\text { days }\end{array}$ & $\begin{array}{l}\text { Used cell phone to } \\
\text { listen to music in past } \\
30 \text { days }\end{array}$ & $\begin{array}{l}\text { Used cell phone } \\
\text { to listen to } \\
\text { podcast in past } \\
30 \text { days }\end{array}$ & $\begin{array}{l}\text { Used cell phone to } \\
\text { watch a movie in } \\
\text { past } 30 \text { days }\end{array}$ & $\begin{array}{l}\text { Used cell phone to } \\
\text { watch live TV In } \\
\text { past } 30 \text { days }\end{array}$ & $\begin{array}{l}\text { Used cell phone to } \\
\text { watch a video clip } \\
\text { in past } 30 \text { days }\end{array}$ \\
\hline Median Age of Population & $-.350 * * *$ & $-.251^{* * *}$ & $-.272^{* * *}$ & $-.273 * * *$ & $-.377^{* * *}$ & $-.371^{* * *}$ & $-.429 * * *$ & $-.356^{* * * *}$ & $-.256^{* * *}$ \\
\hline Asian Population (per capita) & & & $.081^{* * *}$ & $.078^{* * *}$ & & & $.075^{* * * *}$ & $.066^{* * *}$ & \\
\hline $\begin{array}{l}\text { African American Population } \\
\text { (per capita) }\end{array}$ & $.118^{* * *}$ & & & & & $.077^{* * *}$ & $.142^{* * *}$ & $.076^{* * *}$ & $.211^{* * *}$ \\
\hline Hispanic Population (per capita) & $-.083^{* * *}$ & $-.119 * * *$ & $-.124 * * *$ & $-.125^{* * *}$ & $-.082^{* * *}$ & & & & \\
\hline $\begin{array}{l}\text { Persons in Urban area (per } \\
\text { captia) }\end{array}$ & $.384 * * *$ & $.313^{* * *}$ & $.283^{* * *}$ & $.264^{* * *}$ & $.360^{* * *}$ & $.162^{* * *}$ & $.188^{* * *}$ & $.274^{* * *}$ & $.280^{* * *}$ \\
\hline $\begin{array}{l}\text { College Graduates or Higher, } \\
\text { Age } 18+\end{array}$ & & $.274^{* * *}$ & $.267^{* * *}$ & $.222^{* * *}$ & $.120^{* * *}$ & $.471^{* * *}$ & $.414^{* * *}$ & $.391^{* * *}$ & $.246 * * *$ \\
\hline Household Median Income & & $.089 * * *$ & & $.105^{* * *}$ & & & $-.204^{* * *}$ & $-.144 * * *$ & \\
\hline $\begin{array}{l}\text { Persons 16+ Employed (per } \\
\text { capita) }\end{array}$ & & & & & & $-.074 * * *$ & $-.111^{* * *}$ & & \\
\hline $\begin{array}{l}\text { Persons } 16+\text { in Service } \\
\text { Occupations (Per capita) }\end{array}$ & $.095^{* * *}$ & $.100^{* * *}$ & $.075^{* * *}$ & $.085^{* * *}$ & $.075^{* * *}$ & $.059 * * *$ & $.070^{* * *}$ & $.094^{* * *}$ & $.107^{* * *}$ \\
\hline $\begin{array}{l}\text { Persons } 16+\text { in Construction } \\
\text { Occupations (per capita) }\end{array}$ & & & & & & & & & \\
\hline $\begin{array}{l}\text { Persons } 16+\text { in Information } \\
\text { Occupations (per capita) }\end{array}$ & & & & & & & & & \\
\hline $\begin{array}{l}\text { Persons with monthly mobile } \\
\text { phone bills } \$ 1-74 \text { (index) }\end{array}$ & & & & & & & & & \\
\hline $\begin{array}{l}\text { Persons with monthly mobile } \\
\text { phone bills } \$ 75+\text { (index) }\end{array}$ & $.084^{* * *}$ & $.137^{* * *}$ & $.160^{* * *}$ & $.130^{* * *}$ & $.164^{* * *}$ & $.167^{* * *}$ & $.075^{* * *}$ & $.120^{* * *}$ & $.167^{* * *}$ \\
\hline $\begin{array}{l}\text { Persons 16+in Professional, } \\
\text { Scientific, and Technical } \\
\text { Occupations (per capita) }\end{array}$ & $.187^{* * *}$ & $.121^{* * *}$ & $.137^{* * *}$ & $.152^{* * *}$ & $.152^{* * *}$ & & & & $.105^{* * *}$ \\
\hline $\begin{array}{l}\text { Number of patents registered } \\
\text { per county }\end{array}$ & & & & & & & & & \\
\hline Social Capital & $-.087^{* * *}$ & $-.067^{* * *}$ & & & & & $-.048^{* * *}$ & $-.049 * * *$ & \\
\hline $\begin{array}{l}\text { Foreign-born population (per } \\
\text { capita) }\end{array}$ & & & & & & & & & $.077^{* * *}$ \\
\hline Adjusted $\mathrm{R}^{\wedge} \mathbf{2}$ & $.618^{* * *}$ & $.712^{* * *}$ & $.709 * * *$ & $.720^{* * *}$ & $.697^{* * *}$ & $.692^{* * *}$ & $.641^{* * * *}$ & $.690^{* * *}$ & $.713^{* * *}$ \\
\hline Sample Size & 3108 & 3108 & 3108 & 3108 & 3108 & 3108 & 3108 & 3108 & 3108 \\
\hline
\end{tabular}

